\title{
Bioaccumulation of mercury, cadmium, zinc, chromium, and lead in muscle, liver, and spleen tissues of a large commercially valuable catfish species from Brazil
}

\author{
FÁBIO P. ARANTES ${ }^{1}$, LOURENÇO A. SAVASSI ${ }^{1}$, HÉLIO B. SANTOS ${ }^{2}$, MARCOS V.T. GOMES ${ }^{3}$ and NILO BAZZOLI ${ }^{1}$
}

\author{
${ }^{1}$ Programa de Pós-Graduação em Zoologia de Vertebrados, Pontifícia Universidade Católica de \\ Minas Gerais, Av. Dom José Gaspar, 500, 30535-901 Belo Horizonte, MG, Brasil \\ ${ }^{2}$ Laboratório de Patologia Experimental, Universidade Federal de São João Del Rei, Campus Ciências e \\ Saúde, Av. Sebastião Gonçalves Coelho, 400, Chanadour, 35501-296 Divinópolis, MG, Brasil \\ ${ }^{3}$ Centro Integrado de Recursos Pesqueiros e Aquicultura de Três Marias/CODEVASF, \\ Estrada Piscicultura, s/n, 39205-000 Três Marias, MG, Brasil
}

Manuscript received on August 29, 2014; accepted for publication on February 13, 2015

\begin{abstract}
The increasing amounts of heavy metals entering aquatic environments can result in high accumulation levels of these contaminants in fish and their consumers, which pose a serious risk to ecosystems and human health. We investigated the concentrations of mercury $(\mathrm{Hg})$, cadmium $(\mathrm{Cd})$, zinc $(\mathrm{Zn})$, chromium $(\mathrm{Cr})$, and lead $(\mathrm{Pb})$ in muscle, liver, and spleen tissues of Pseudoplatystoma corruscans specimens collected from two sites on the Paraopeba River, Brazil. The level of heavy metals concentrations in the tissues was often higher in viscera (i.e. liver and spleen) than in muscle, and thus, the viscera should not be considered for human consumption. Correlations between metal concentrations and fish size were not significant. Although the levels of muscle bioaccumulation of $\mathrm{Hg}, \mathrm{Cd}, \mathrm{Zn}, \mathrm{Cr}$, and $\mathrm{Pb}$, generally do not exceed the safe levels for human consumption, the constant presence of heavy metals in concentrations near those limits considered safe for human consumption, is a reason for concern, and populations who constantly consume fish from polluted rivers should be warned. Our findings also indicate that in a river network where certain areas are connected to other areas with high rates of environmental pollutants, people should be cautious about the regular consumption of fish, even when the fish consumed are caught in stretches of the basin where contamination levels are considered low, since many of the freshwater fish with high commercial value, such as the catfish surubim, are migratory.
\end{abstract}

Key words: contamination, freshwater fish, heavy metal, human health.

\section{INTRODUCTION}

In the last decades, the rapid development of industry and agriculture has resulted in increased heavy metals pollution, which is a significant environmental hazard for invertebrates, fish, and humans (Uluturhan and Kucuksezgin 2007). Among the contaminants, heavy metals should

Correspondence to: Nilo Bazzoli

E-mail: bazzoli@pucminas.br be highlighted due to the consequences of their bioaccumulation in aquatic ecosystems (Nadmitov et al. 2014, Marques et al. 2009, Sloman 2007). Significant quantities of these metals are discharged into rivers, where they can be strongly accumulated and biomagnified in water, sediment, and the aquatic food chain, resulting in both sub-lethal effects or death in local fish populations (Megeer et al. 2000, Protano et al. 2014, Xie et al. 2014, Xu et al. 2004). 
The toxicity of trace metals has long been a concern, considering they are not removed from aquatic ecosystems by self-purification (Harikumar and Nasir 2010) and accumulate in suspended particulates and sediments (De Jonge et al. 2012), thereby potentially threatening human health and ecosystems via the food web (Eslami et al. 2011). Consequently, evaluating the ecological risk from trace elements has become a hot topic (Mario et al. 2012).

Heavy metals enter the aquatic environment from both natural pathways and a variety of anthropogenic sources (Youn-Joo 2003), and they can have a negative impact on aquatic ecosystems, the food chain, and human health. The concentration of heavy metals in biological compartments, such as fish muscle, is a complex combination of biological and ecological variables (Barletta et al. 2012). In fish, these elements can cause disturbances in growth and reproduction, as well as histopathological alterations in the skin, gills, liver, spleen, and kidneys (Vitek et al. 2007). In addition, some metals may decrease the plasticity of the cardiorespiratory responses, reducing the survival chances of fish under hypoxic conditions, which has been frequently observed in their wild habitats (Monteiro et al. 2013). In humans, heavy metals accumulation has hazardous effects on the brain, liver, kidneys, lungs, and muscles (Petera and Viraraghavanb 2005, Youn-Joo 2003). For these reasons, evaluation of heavy metal levels in commercially important fish is important from a toxicological perspective, verifying whether there is a significant health risk arising from fish consumption.

Currently, some physiological and histopathological biomarkers of fish have been extensively used to document and quantify the effects of pollutants in aquatic environments, such as follicular atresia, heat shock proteins, apoptosis, metallothionein, vitellogenin in males, hormonal disturbances, melanomacrophagic centres (MMCs), fibrosis, and steatosis in teleosts (Santos et al. 2005,
Prado et al. 2011). Many studies suggest that the general function of the MMC is the centralisation of destruction, detoxification, or recycling of endogenous and exogenous materials (Vogelbein et al. 1987, Ellis et al. 1976). An increase of MMC numbers and size has often been associated with degraded environmental conditions (Agius and Roberts 2003, Ribeiro et al. 2011).

The surubim catfish (Pseudoplatystoma corruscans) is one of the most important highvalue species in Brazil (Roubach et al. 2003) reaching $180 \mathrm{~cm}$ in length and $100 \mathrm{~kg}$. The surubim is a nocturnal piscivorous fish in any habitats, seasons, or sizes (Agostinho et al. 2004). Demand for the species as a food, sport and ornamental fish, together with the effects of anthropic actions, has caused the decline of the natural stocks (Campos 2005). Published studies have focused on surubim biology (Mateus and Petrere Jr 2004), reproduction (Brito and Bazzoli 2003), and nutrition (Martino et al. 2005). However, there are few studies about surubim meat quality and the contamination levels of these fish in nature.The São Francisco River basin is one of the most important in Brazil, with drainage areas in five states, and crossing three biomes. One of its main tributaries is the Paraopeba River, located in the state of Minas Gerais crossing 35 municipalities (IGAM 2005).

We investigated accumulation level of mercury $(\mathrm{Hg})$, cadmium $(\mathrm{Cd})$, zinc $(\mathrm{Zn})$, chromium $(\mathrm{Cr})$ and lead $(\mathrm{Pb})$ in the muscle, liver and spleen tissues of $P$. corruscans, to determine whether specific elements exceeded the maximum acceptable concentrations for human consumption (ANVISA 1998).

\section{MATERIALS AND METHODS}

This study was conducted in accordance with the Brazilian legislation (Law \#11.794, October 8 , 2008). All capture, holding, and experimental techniques were performed in accordance with the Committee of Ethics in Animal Experimentation's (CEUA) regulations. 
The analyzed fish were captured at two sites on the Paraopeba River (Fig. 1): Section A - just downstream of the Igarapé thermoelectric power plant (19 $57^{\prime} 50.24$ " S, $44^{\circ} 16^{\prime} 52.42^{\prime}$ W), and Section B - just downstream of the Retiro Baixo hydroelectric power plant (18 ${ }^{\circ} 52^{\prime} 28.64$ ' $\mathrm{S}, 4^{\circ}{ }^{\circ} 46^{\prime}$ 50.27 ' W). Section A, is characterised as a highly impacted site, with its water contaminated by waste from the electroplating and steel industries, agriculture, and sewage, with contaminants exceeding safe levels for human health (IGAM 2012). On the other hand, section B, has much better water quality (IGAM 2012). Samples were collected from 32 specimens of $P$. corruscans (11 males and 21 females), from December 2010 to
December 2012. The body length of the fish ranged from 55.0 to $90.0 \mathrm{~cm}$ for males and from 60.0 to $124.0 \mathrm{~cm}$ for females, and the body weight ranged from 1.1 to $8.88 \mathrm{~kg}$ for males and 1.62 to $18.54 \mathrm{~kg}$ for females.

For heavy metals analyses, fragments of the right dorsal muscle, spleen, and liver were collected and stored at $-20{ }^{\circ} \mathrm{C}$ prior to analysis. The analytical method used for determining the concentration of total mercury $(\mathrm{Hg})$ in fish samples was based on thermal decomposition with detection by atomic absorption spectrometry, following the recommendations of the U.S. Environmental Protection Agency - EPA 7473 (1998). Data were expressed in $\mu \mathrm{g} / \mathrm{g}^{-1}$ for wet

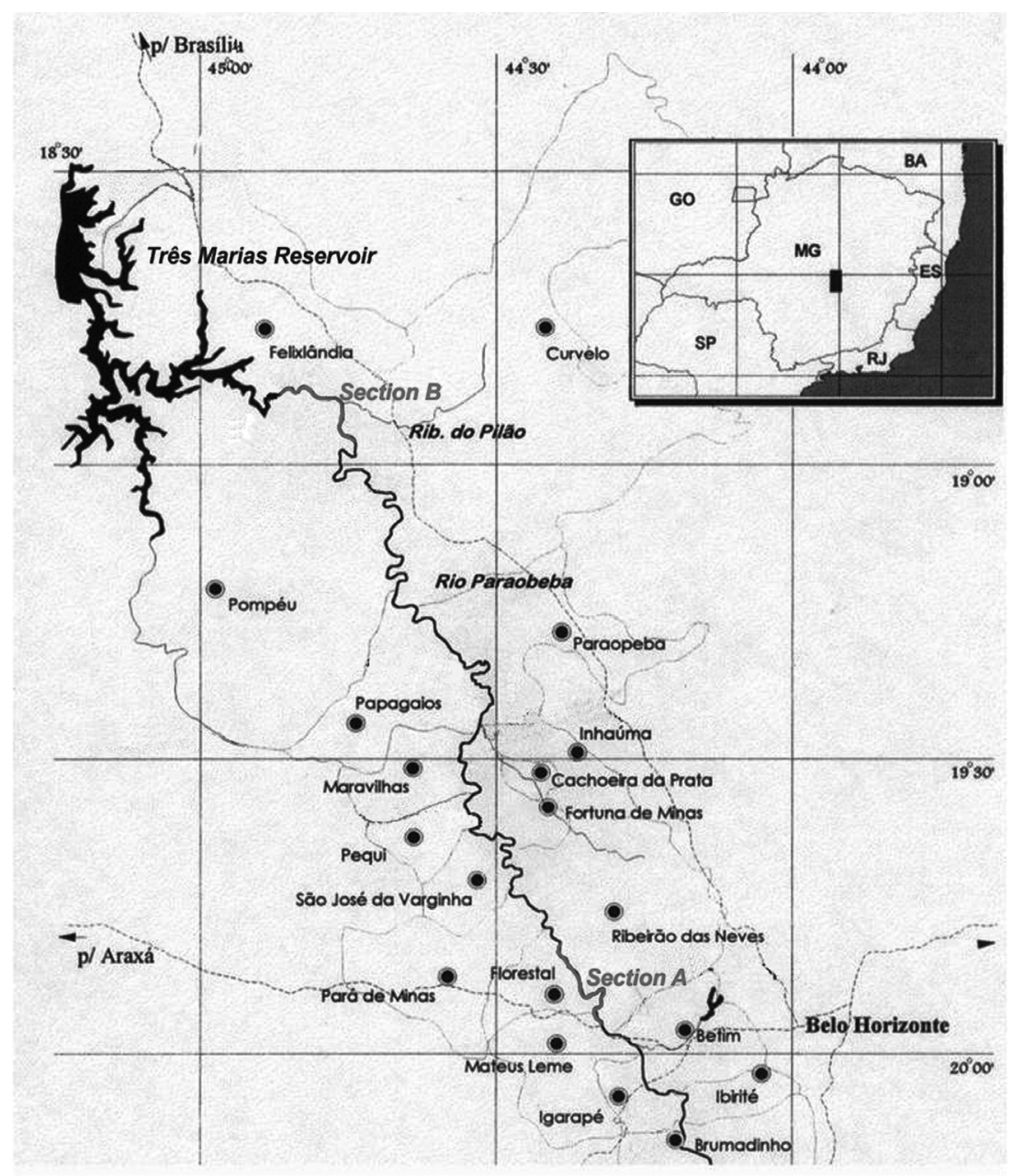

Figure 1 - Map of the Paraopeba River showing the location of sampling sites for the current study: Section A and Section B. (See the colors in the online version.) 
weight. The determination of the concentration of $\mathrm{Cd}, \mathrm{Zn}, \mathrm{Cr}$, and $\mathrm{Pb}$ in the samples was based on acid decomposition in a closed vessel device using microwaves (U.S. EPA-3052, 1996), and detection by atomic absorption spectrometry, performed in an atomic absorption spectrophotometer with flame and graphite furnace, model iCE 3500, Thermo Fisher Scientific brand. To certify the accuracy of the analysis, measurements of heavy metals for two reference materials were performed, where the recovery rates (average) were $99.2 \%$ and $95.5 \%$.

Fragments of the liver and spleen of all fish caught were removed and fixed in Bouin's fluid for 8-12 h at room temperature, stored in $80 \%$ alcohol, and embedded in paraffin. At least 3 sections of each fragment (3-5 $\mu \mathrm{m}$ thickness) were stained with haematoxylin-eosin or Gomori's trichrome. Morphological analyses were performed to detect MMCs. The morphometry was performed under a light microscope coupled to a 5.0 megapixel digital camera and computer using the Motic Images Plus 2.0 image analyzer software. We calculated the total area of each histological section, area of each individual melanomacrophage centre, total area of the MMCs, and performed a count of the MMCs.

We also analyzed the relationship between the levels of contamination in P. corruscans with fish size, sex, and sampling site (section A and B). The relationship between the levels of contamination by $\mathrm{Cd}, \mathrm{Pb}, \mathrm{Cr}, \mathrm{Hg}$, and $\mathrm{Zn}$ from the liver, spleen and muscle were analyzed. Descriptive statistics for biological variables were performed using GraphPad InStat (Software Inc., Version 3.05, San Diego, CA, USA), and the values were expressed as the means \pm standard deviation (SD). The data were analyzed using the KS normality test. When the distribution was not normal, the data were analyzed by the nonparametric Kruskal-Wallis Test (Non Parametric ANOVA) with Dunn post-test to verify the existence of significant differences between the parameters $(P<0.05)$. When the distribution was normal, the data were analyzed by an unpaired
T-test (when the standard deviation was equal) and unpaired $\mathrm{T}$ test with Welch correction, when the standard deviation was different. The confidence interval was $95 \%$.

\section{RESULTS}

The analysis of heavy metals showed the presence of $\mathrm{Hg}, \mathrm{Cd}, \mathrm{Zn}, \mathrm{Cr}$, and $\mathrm{Pb}$ in the spleen, liver, and muscle of all analyzed samples (Fig. 2). The livers showed higher levels of contamination for $\mathrm{Cd}$ and $\mathrm{Zn}$, while the spleens showed higher levels of $\mathrm{Cr}$ (Fig. 2). It is also important to highlight that levels of $\mathrm{Hg}$ and $\mathrm{Pb}$ were higher or similar in muscle tissue compared to the liver and spleen.

The statistical analysis showed significant differences between the levels of heavy metals in the surubim collected from the two sections from Paraopeba River (Table I). For muscles, a significant difference in $\mathrm{Cd}$ and $\mathrm{Zn}$ levels was observed for fish from section A as compared to those from section B. Furthermore, the livers and spleens, showed significant differences for $\mathrm{Pb}$ between the sampling sites. Lastly, the $\mathrm{Cr}$ concentration was high in the spleens of fish caught in section A.

A positive correlation between fish size and levels of contamination was registered only for some of the analyzed metals, such as $\mathrm{Hg}$, which was positively correlated in males and females for all analyzed tissues (Table II). Furthermore, there was no positive correlation between fish size and the levels of contamination by $\mathrm{Pb}$ for any of the tissues analyzed.

The histological analysis showed MMCs in the livers (Fig. 3a) and spleens (Fig. 3b). These structures were formed by macrophage aggregates, which presented pigmented material varying from pink to red and light brown to dark brown (Fig. 3c). The MMCs were associated to blood vessels (Fig. $3 \mathrm{c}$ and $\mathrm{d}$ ), presenting a spherical or irregular shape (Fig. 3a-f), and varying in their individual size (Table III). Moreover, different levels of fibroses were observed in the liver (Fig. 3e-f). 

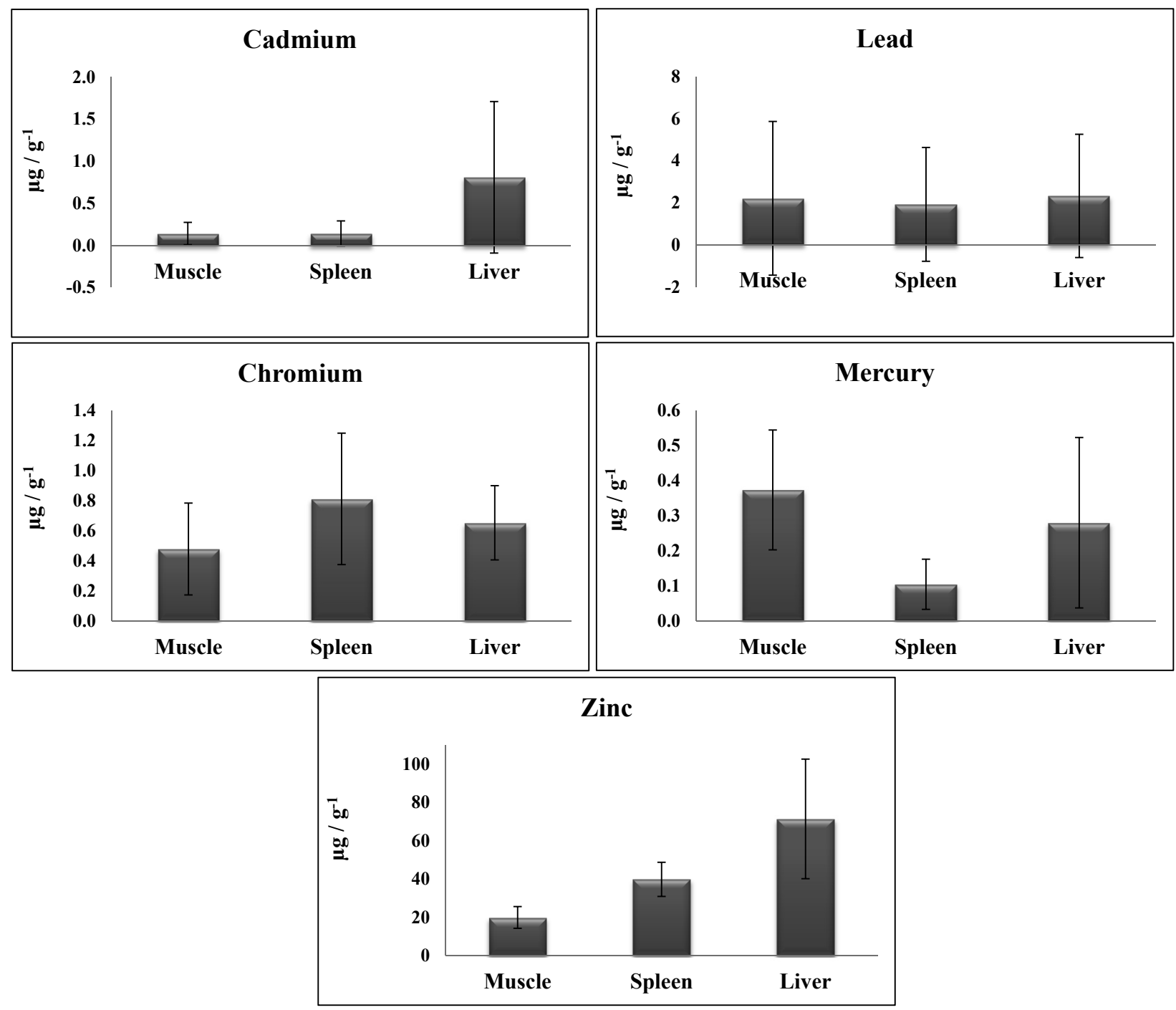

Figure 2 - Bioaccumulation ( $\mu \mathrm{g} / \mathrm{g}^{-1}$ wet weight) of $\mathrm{Cd}, \mathrm{Pb}, \mathrm{Cr}, \mathrm{Hg}$ and $\mathrm{Zn}$ in muscle, spleen and liver tissues of $P$. corruscans. Mean and standard deviation. The different letters mean statistically significant differences $(p<0.05)$ to the values in the same graph.

TABLE I

Bioaccumulation ( $\mu \mathrm{gg}^{-1}$ wet weight) of cadmium, zinc, lead, chromium, and mercury in muscle, liver and spleen of $P$. corruscans from two sections of the Paraopeba River. Data expressed in mean \pm standard deviation.

\begin{tabular}{cccccccccc}
\hline & \multicolumn{3}{c}{ Muscle } & & \multicolumn{2}{c}{ Liver } & & \multicolumn{3}{c}{ Spleen } \\
\cline { 2 - 10 } & Section A & Section B & & Section A & Section B & & Section A & Section B \\
\hline Cd & $0.07 \pm 0.06$ & $0.19 \pm 0.15$ & $\mathbf{s}$ & $0.65 \pm 0.61$ & $0.97 \pm 1.09$ & $\mathbf{n s}$ & $0.08 \pm 0.05$ & $0.19 \pm 0.18$ & $\mathbf{n s}$ \\
$\mathbf{Z n}$ & $17.81 \pm 4.23$ & $21.71 \pm 6.28$ & $\mathbf{s}$ & $69.54 \pm 28.07$ & $72.45 \pm 35.87$ & $\mathbf{n s}$ & $43.35 \pm 12.32$ & $37.6 \pm 4.91$ & $\mathbf{n s}$ \\
$\mathbf{P b}$ & $0.94 \pm 0.98$ & $3.31 \pm 4.64$ & $\mathbf{n s}$ & $1.03 \pm 0.67$ & $3.37 \pm 3.66$ & $\mathbf{s}$ & $0.67 \pm 0.37$ & $2.96 \pm 3.35$ & $\mathbf{s}$ \\
$\mathbf{C r}$ & $0.54 \pm 0.42$ & $0.42 \pm 0.32$ & $\mathbf{n s}$ & $0.72 \pm 0.23$ & $0.59 \pm 0.26$ & $\mathbf{n s}$ & $1.04 \pm 0.53$ & $0.66 \pm 0.28$ & $\mathbf{s}$ \\
$\mathbf{H g}$ & $0.41 \pm 0.18$ & $0.35 \pm 0.17$ & $\mathbf{n s}$ & $0.26 \pm 0.01$ & $0.31 \pm 0.32$ & $\mathbf{n s}$ & $0.11 \pm 0.08$ & $0.11 \pm 0.06$ & $\mathbf{n s}$ \\
\hline
\end{tabular}

$\mathrm{ns}=$ not significant; $\mathrm{s}=$ significant. 
TABLE II

Relationship between the levels of cadmium, chromium, lead, mercury and zinc contamination in liver, spleen and muscle and the body size of $P$. corruscans.

\begin{tabular}{lllllll}
\hline \multirow{2}{*}{ Female } & Cd & Cr & Pb & Hg & Zn \\
& Liver & 0.91 & 0.47 & -0.02 & 0.95 & 0.05 \\
& Spleen & 0.71 & -0.39 & -0.09 & 0.63 & 0.25 \\
& Muscle & -0.02 & 0.06 & -0.04 & 0.54 & -0.07 \\
\hline \multirow{2}{*}{ Male } & Liver & -0.05 & 0.07 & -0.01 & 0.59 & -0.45 \\
& Spleen & -0.20 & -0.37 & -0.28 & 0.38 & -0.62 \\
& Muscle & 0.33 & 0.38 & 0.04 & 0.40 & 0.50 \\
\hline
\end{tabular}
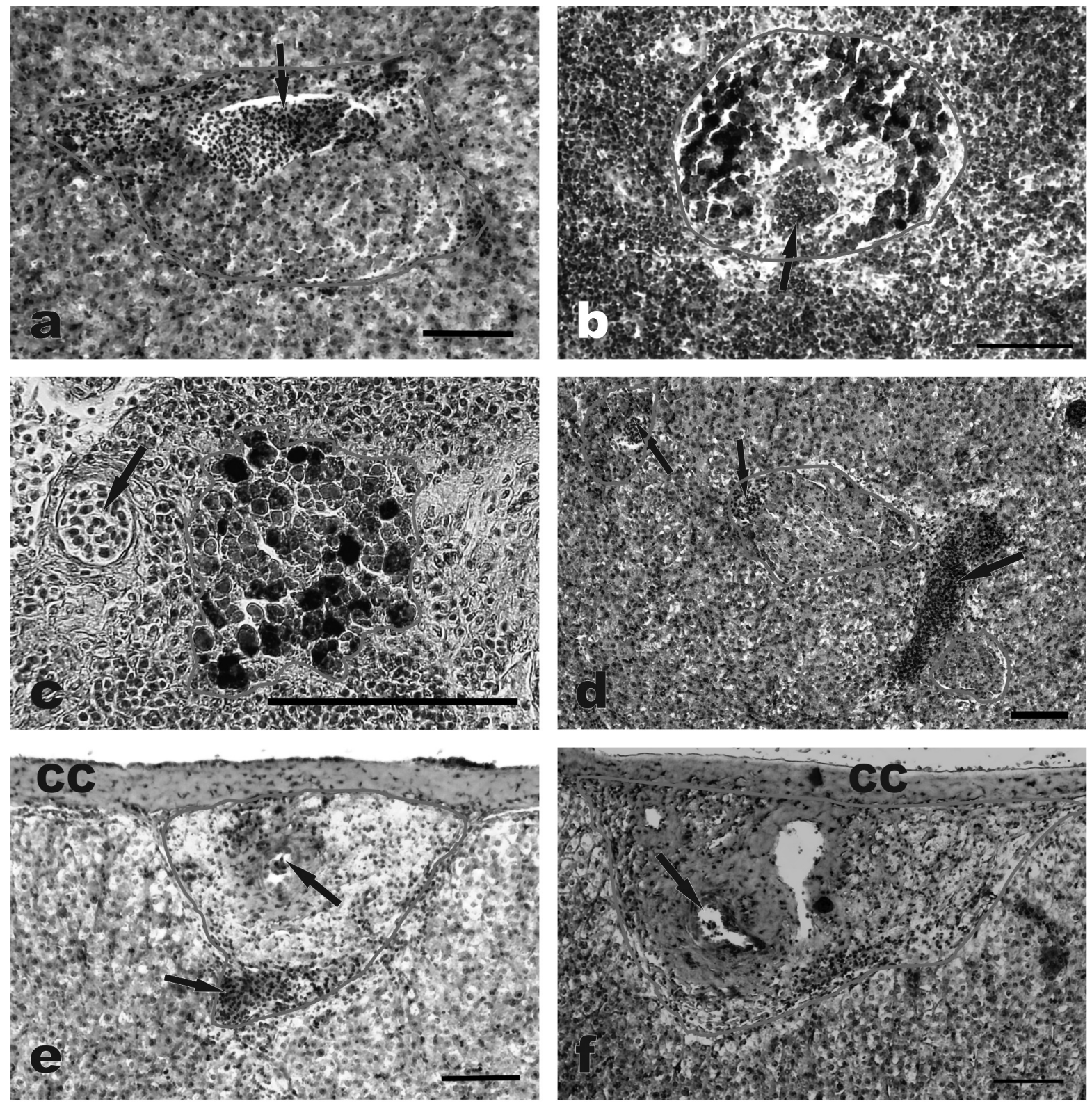

Figure 3 - Histological sections of liver (a, d, e and $\mathbf{f}$ ) and spleen (b and $\mathbf{c}$ ) of $P$. corruscans showing MMCs (inside the circles) in association with blood vessels (arrows). MMCs distributed throughout the parenchyma of the organs a-d, and adhered to the liver conjunctiva capsule (e and f). Gomori's trichrome stain. Scale bar corresponds to $100 \mu \mathrm{m}$. (See the colors in the online version.) 
For the liver, melanomacrophagic centres (MMCs) occurred in 63\% of fish collected in section $\mathrm{A}$ and $77 \%$ of those in Section B. In relation to the spleen, the presence of MMCs was detected in $100 \%$ of the fish from section $\mathrm{A}$ and in $92 \%$ of fish from section B. The largest total area occupied by MMCs (1.24\% of the analyzed tissue), and the largest number of MMCs (555 centres) were recorded in the spleens. Meanwhile, the liver registered the highest area occupied by a single MMC, 5,467 $\mu \mathrm{m}^{2}$ (Table III).

Statistical analyses showed no significant relationship between the presence or morphology of MMCs and the length/weight of the fish (Table III), nor any relationship to the sex of the individuals. However, correlations between the MMCs and levels of contamination by $\mathrm{Pb}, \mathrm{Cd}, \mathrm{Cr}, \mathrm{Hg}$ and $\mathrm{Zn}$ were observed. We only observed a significant positive relationship between the number of MMCs and the area occupied by them in the livers to the concentration of $\mathrm{Hg}$.

Considering the two length classes (63-75 and $76-88 \mathrm{~cm}$ ) of the fish caught in the two sections sampled from Paraopeba River, we observed that the fish collected from section A, had a higher number of MMCs, both in the liver and in the spleen, and greater individual area occupied by MMCs in the livers, whereas fish collected from section $\mathrm{B}$ showed a larger area occupied by an individual MMC in the spleen. Fish from the section A, which has higher pollution levels and belong to the length class 76-88 cm showed larger total areas occupied by MMCs in the livers and spleens.

\section{DISCUSSION}

Fish are an important source of food and represent a major part of many natural food chains. Therefore, the levels of contaminants in fish are of particular interest because of the potential effects of these polluting substances on the fish themselves and on the organisms that consume them, including humans (Burger and Gochfeld 2005). Our results showed the presence of $\mathrm{Hg}, \mathrm{Cd}, \mathrm{Zn}, \mathrm{Cr}$, and $\mathrm{Pb}$ in all $P$. corruscans collected from the Paraopeba River. Moreover, the results indicated a variation between the heavy metals levels in the analyzed muscle, liver, and spleen tissues, as also registered by Taweel et al. (2013).

In general, the levels of heavy metals accumulation in $P$. corruscans were greater in the liver, spleen, and muscle, respectively. Sindayigaya et al. (1994) found higher levels of $\mathrm{Zn}$ and $\mathrm{Cd}$ in

TABLE III

Individual area, total area and number of MMCs per $\mathbf{m m}^{2}$ in liver and spleen of $P$. corruscans. Data expressed as mean \pm standard deviation and range, with $p$ value (Mann-Whitney test).

\begin{tabular}{|c|c|c|c|c|c|}
\hline & & & Male & Female & $p$ \\
\hline \multirow{4}{*}{$\begin{array}{l}\text { Individual area of } \\
\text { MMC's }\left(\mu \mathrm{m}^{2}\right)\end{array}$} & \multirow{2}{*}{ Liver } & $\mathrm{M} \pm \mathrm{SD}$ & $716.7 \pm 792.2$ & $908.9 \pm 1361.3$ & 0.89 \\
\hline & & Range & $188.0-2345.0$ & $227.0-5467.0$ & \\
\hline & \multirow{2}{*}{ Spleen } & $\mathrm{M} \pm \mathrm{SD}$ & $1058.5 \pm 1157.7$ & $653.76 \pm 660.15$ & 0.37 \\
\hline & & Range & $157.0-3461.0$ & $173.0-3024.0$ & \\
\hline \multirow{4}{*}{$\begin{array}{c}\text { Total area of MMC's } \\
(\%)\end{array}$} & \multirow{2}{*}{ Liver } & $\mathrm{M} \pm \mathrm{SD}$ & $0.06 \pm 0.1$ & $0.10 \pm 0.2$ & 0.84 \\
\hline & & Range & $0-0.4$ & $0-0.6$ & \\
\hline & \multirow{2}{*}{ Spleen } & $\mathrm{M} \pm \mathrm{SD}$ & $0.52 \pm 0.4$ & $0.33 \pm 0.2$ & 0.19 \\
\hline & & Range & $0-1.2$ & $0.01-0.7$ & \\
\hline \multirow{4}{*}{$\begin{array}{l}\text { Number of MMC's / } \\
1000 \mathrm{~mm}^{2}\end{array}$} & \multirow{2}{*}{ Liver } & $\mathrm{M} \pm \mathrm{SD}$ & $1.6 \pm 1.5$ & $0.82 \pm 0.6$ & 0.09 \\
\hline & & Range & $0-5.1$ & $0-1.8$ & \\
\hline & \multirow{2}{*}{ Spleen } & $\mathrm{M} \pm \mathrm{SD}$ & $10.5 \pm 10.2$ & $8.08 \pm 6.6$ & 0.18 \\
\hline & & Range & $0.4-32.5$ & $0-23.5$ & \\
\hline
\end{tabular}


fish livers in comparison to other organs. The liver is often used as a reference for analysis of tissue damage caused by environmental toxic compounds (Amaral et al. 2002).

Although there is a relationship between the levels of contamination of the aquatic environment with the bioaccumulation of heavy metals in fish, our results showed that only $\mathrm{Cr}$ in the spleen of $P$. corruscans was detected at significantly higher levels of contamination in section A (i.e., the section with higher levels of pollutants). This result could be related to the fact that migratory fish like $P$. corruscans can move between sites with higher levels of pollutants and less degraded places. Consequently, consumption of fish can be dangerous even when these fish are caught in areas considered to have low rates of contamination. Furthermore, in our findings, it was not possible to verify any relationship between the levels of heavy metals bioaccumulation to the sex of the analyzed fish, as has previously been reported by Kehrig et al. (2008) for other Brazilian commercially important fish.

In our study, concentrations of $\mathrm{Hg}$ and $\mathrm{Cd}$ increased in accordance to fish size, whilst no significant concentration-size relationship was found for the other metals, indicating that accumulation of $\mathrm{Pb}, \mathrm{Zn}$, and $\mathrm{Cr}$ in $P$. corruscans from the Paraopeba River is not necessarily related to age. Barone et al. (2013) also found a significant concentration-size relationship for $\mathrm{Hg}$ in livers of two fish species. Due to their cumulative potential, high levels of $\mathrm{Hg}$ in fish, present a significant risk in the aquatic ecosystem, as well as to human health (Dang and Wang 2012).

In the present study, the muscles exhibited high levels of $\mathrm{Hg}$ contamination, and the $\mathrm{Hg}$ levels were also positively correlated to body weight, confirming the theory of bioaccumulation from continuous exposure to the metal, as also recorded by Seixas et al. (2012). As reported for other fish (Sellanes et al. 2002), in our work, muscle samples with levels of $\mathrm{Hg}$ contamination above the safe limit for human consumption (ANVISA 1998) were not recorded. Despite this, we note that in all the fish analyzed we detected the presence of $\mathrm{Hg}$, including some cases of levels near the safe limit for human consumption. Furthermore, the elevated levels of $\mathrm{Pb}$ contamination observed in the liver, spleen, and muscle of $P$. corruscans do exceed the safe limit for human consumption. Astyanax sp. from another Brazilian river presented high concentrations of lead in its muscles and viscera (Jordão et al. 1999). As in mammals, the principal effects of chronic $\mathrm{Pb}$ exposure on fish are presumably haematological (Schmitt et al. 2002), neurological (Noureddine et al. 2005) and renal (Patel et al. 2006) impairment. Although the presence of $\mathrm{Cd}$ in muscle, liver and spleen tissues was detected in all examined fish, Cd levels above those considered safe for human consumption were only registered in hepatic tissue, reinforcing the hypothesis that the liver would actually be a target organ for processing and bioaccumulation of heavy metals (Sindayigaya et al. 1994).

The melanomacrophagic centres (MMCs) act upon the centralisation of destruction and detoxification of endogenous and exogenous materials (Rabitto et al. 2005). In P. corruscans's spleen, the MMCs occurred mainly close to ellipsoids, and such proximity is related to the fact that ellipsoids have a high filtration capacity and capture pathogens, which can subsequently be conducted to the MMC in the spleen (Danneving and Landsverk 1995). In P. corruscans liver, the MMCs were mainly observed near hepatic veins and arteries, indicating their interaction with the blood system. This result showed that the amount or area occupied by MMCs in the spleens and livers of $P$. corruscans is not directly correlated to the size and weight of the fish, unlike that observed for other teleosts (Haaparanta et al. 1996). Moreover, there was also no significant correlation between the MMCs and the sex of the individuals analyzed. Thus, our findings indicate that MMCs in P. corruscans (at least partly) are physiologically decreased and 
are more related to the level of environmental stress in which the fish are found at the moment, than to their size or sex, which therefore shows that MMCs are not cumulative throughout the life of the fish. An increased MMC presence in the spleen and liver has often been associated with degraded environmental conditions (Agius and Roberts 2003). Corroborating these authors, our results showed that the MMCs in fish captured from section A (high pollution levels) are larger than section B. A positive correlation between the quantity and the area occupied by the MMCs and bioaccumulation of heavy metal was only significant for $\mathrm{Hg}$ in the liver. This result contrasts with that registered by Rabitto et al. (2005), where $\mathrm{Pb}$ contamination in Hoplias malabaricus resulted in increased MMCs and a reduction of free macrophages.

In conclusion, the present study provides crucial information on the distribution of heavy metals in tissues of a fish with great economic importance, showing that the viscera (i.e., liver and spleen) usually contain high amounts of heavy metals, and should thus not be considered for human consumption. Although the levels of muscle bioaccumulation of $\mathrm{Hg}, \mathrm{Cd}, \mathrm{Zn}, \mathrm{Cr}$, and $\mathrm{Pb}$ in the analyzed samples of $P$. corruscans generally do not exceed the safe levels for human consumption (ANVISA 1998), the constant presence of heavy metals in concentrations near those considered safe for human consumption is a reason for warning populations who regularly consume fish from the Paraopeba River. Moreover, our results indicate that in a river network where there are connected areas with high rates of environmental pollutants, consumption of fish can be dangerous even when these fish are caught in areas considered to have low rates of contamination.

\section{ACKNOWLEDGMENTS}

The researchers would like to thank Coordenação de Aperfeiçoamento de Pessoal de Nível Superior (CAPES), Fundação de Amparo à Pesquisa do Estado de Minas Gerais (FAPEMIG), and Con- selho Nacional de Desenvolvimento Científico e Tecnológico $(\mathrm{CNPq})$ for their financial support and Companhia de Desenvolvimento dos Vales do São Francisco e do Parnaíba (CODEVASF) for their support with the analysis of heavy metals.

\section{RESUMO}

O aumento da entrada de metais pesados nos ambientes aquáticos pode resultar em altos níveis de acumulação destes contaminantes nos peixes e seus consumidores, representando um risco para os ecossistemas e para a saúde humana. Investigamos as concentrações de mercúrio $(\mathrm{Hg})$, cádmio $(\mathrm{Cd})$, zinco $(\mathrm{Zn})$, cromo $(\mathrm{Cr})$ e chumbo $(\mathrm{Pb})$ nos tecidos do músculo, fígado e baço de Pseudoplatystoma corruscans, coletado em dois trechos do rio Paraopeba, Brasil. Nossos resultados mostraram que as concentrações dos metais pesados foram mais elevadas nas vísceras, isto é fígado e baço, indicando que as vísceras de $P$. corruscans não devem ser utilizadas para consumo humano. As correlações entre as concentrações de metais pesados e o tamanho dos peixes não foram estatisticamente significativas. Embora os níveis de $\mathrm{Hg}, \mathrm{Cd}, \mathrm{Zn}, \mathrm{Cr}$ e $\mathrm{Pb}$ no músculo geralmente não tenham ultrapassado os limites seguros para o consumo humano, a presença constante desses metais em concentrações próximas a estes limites é motivo de alerta para as populações que consomem regularmente peixes de rios poluídos como o rio Paraopeba. Nossos resultados também indicaram que em uma rede fluvial, onde existam áreas poluídas conectadas a ambientes de boa qualidade, o consumo regular de peixes, mesmo quando estes são capturados em trechos onde os níveis de contaminação forem considerados baixos, pode oferecer risco à saúde, uma vez que muitos peixes de água doce com alto valor comercial como $P$. corruscans são migradores.

Palavras-chave: contaminação, peixes de água doce, metal pesado, saúde humana.

\section{REFERENCES}

AgIUs C AND RoBerTs RJ. 2003. Melano-macrophage centers and their role in fish pathology. J Fish Dis 26: 499512.

Agostinho AA, Gomes LC, ThOMAZ SM AND HAHN NS. 2004. The Upper Paraná river and its floodplain: main 
characteristics and perspectives for management and conservation. In: Thomaz SM, Agostinho AA and Hahn NS (Eds), The Upper Paraná River and its floodplain: physical aspects, ecology and conservation. Leiden: Backhuys Publishers, p. 381-393.

Amaral AF, Alvarado N, MARigómez I, CUnHA R, HYLLAND K AND SOTO M. 2002. Autometallography and metallothionein immunohistochemistry in hepatocytes of turbot (Scophthalmus maximus l.) after exposure to $\mathrm{Cd}$ and further depuration treatment. Biomarkers 7: 491-500.

ANVISA - AGÊNCIA NACIONAL DE VIGILÂNCIA SANITÁRIA. 1998. Tolerance limits of inorganic contaminants in food. Ordinance № 685 of August, 1998, Brasil.

BARLETTA M, LUCENA LRR, COSTA MF AND CYSNEIROS FJA. 2012. The interaction rainfall vs. weight as determinant of total mercury concentration in fish from a tropical estuary. Environ Pollut 167: 1-6.

BArone G, Stuffler RG AND Storelli M. 2013. Comparative study on trace metal accumulation in the liver of two fish species (Torpedinidae): Concentration-size relationship. Ecotox Environ Safe 97: 73-77.

BRITO MFG AND BAZZOLI N. 2003. Reproduction of the surubim catfish (Pisces, Pimelodidae) in the São Francisco River, Pirapora. Arq Bras Med Vet Zoot 55: 624-633.

Burger J AND GOCHFELD M. 2005. Heavy metals in commercial fish in New Jersey. Environ Res 99: 403-412.

CAmpos JL. 2005. O cultivo do pintado, Pseudoplatystoma corruscans (Spix e Agassiz, 1829). In: Baldisserotto B and Gomes LC (Eds), Espécies nativas para piscicultura no Brasil. Cap.14. Santa Maria: UFSM, p. 327-343.

DANG F AND WANG WX. 2012. Why mercury concentration increases with fish size? Biokinetic explanation. Environ Pollut 163: 192-198.

DANNEVING DH AND LANDSVERK T. 1995. Immunecomplex trapping in the splenic ellipsoids of rainbow trout (Oncorhynchus mykiss). Cell Tissue Res 282: 41-48.

De Jonge M, Belpaire C, GeERAERTS C, De COOMAN W, Blust R AND Bervoets L. 2012. Ecological impact assessment of sediment remediation in a metalcontaminated lowland river using translocated zebra mussels and resident macroinvertebrates. Environ Pollut 171: 99-108.

Ellis AE, Munro AL AND Roberts RJ. 1976. Defense mechanisms in fish. A study of the phagocytic system and the fate of intraperitonally injected particulate material in the plaice (Pleuronectes platessa). J Fish Biol 8: 67-78.

ESLAMI S, HAJIZADEH MOGHADDAM A, JAFARI N, NABAVI SF, NABAVI SM AND EBRAHIMZADEH MA. 2011. Trace element level in different tissues of Rutilus frisii kutum Collected from Tajan River, Iran. Biol Trace Elem Res 143: 965-973.

HaAparanta A, TElLERVo E, HofFMANN R AND HOLMES J. 1996. Do macrophage centres in freshwater fishes reflect the difference in water quality? Aquatic Toxicol 12: 217-222.

HARIKUMAR PS AND NASIR UP. 2010. Ecotoxicological impact assessment of trace elements in core sediments of a tropical estuary. Ecotoxicol Environ Safe 73: 1742-1747.

ICES. 2006. Report of the Working Group on Biological Effects of Contaminants (WGBEC), 27-31 March 2006, Copenhagen, Denmark. ICES CM 2006/MHC:04, 79 p.

IGAM. 2005. Estudos das Metas de Qualidade da Bacia Hidrográfica do Rio Paraopeba. Available in: http:// comites.igam.mg.gov.br/comites-estaduais/bacia-do-riosao-francisco/sf3-cbh-do-rio-paraopeba/1104-conheca-abacia. Acess in september/2013.

IGAM. 2012. Monitoramento da qualidade das águas superficiais no estado de Minas Gerais, Brasil. Quarterly report available in: http://www.igam.mg.gov.br/images/ stories/qualidade/2013/relatorio-trimestral-am-3otrim-2012.pdf .

JoRdÃo CP, SILVA AC, PEREIRA JL AND BRUNE W. 1999. Contaminação por cromo de águas de rios proveniente de curtumes em Minas Gerais. Quím 22: 47-52.

KEHRIG HA, HowARD BM AND MALM O. 2008. Methylmercury in a predatory fish (Cichla spp.) inhabiting the Brazilian Amazon. Environ Pollut 154: 68-76.

Mario C, VAleria D, GeORG H AND Stefano P. 2012. Guidance for sediment and biotamonitoring under the Common Implementation Strategy for the Water Framework Directive. Trac Trend Anal Chem 36: 15-24.

MARQUES DC, MATTA SLP, OLIVEIRA JA AND DERGAM JA. 2009. Alterações histológicas em brânquias de Astyanax bimaculatus causadas pela exposição aguda ao zinco. Rev Bras Toxicol 22: 26.

MARTINO RC, CYRINO JEP, PORTZ L AND TRUGO LC. 2005. Performance, carcass composition and nutrient utilization of surubim Pseudoplatystoma corruscans (Agassiz) fed diets with varying carbohydrate and lipid levels. Aquacult Nutr 11: 131-137.

Mateus LAF AND Petrere JR M. 2004. Age, growth and yield per recruit analysis of the Pintado Pseudoplatystoma corruscans (Agassiz, 1829) in the Cuiabá River Basin, Pantanal Matogrossense, Brazil. Braz J Biol 64: 257-264.

MEgeER J, SzeBedinszKy C, MCDONALD D AND WoOD CM. 2000. Effect of chronic sublethal exposure to waterborne $\mathrm{Cu}, \mathrm{Cd}$, or $\mathrm{Zn}$ in rainbow trout. Iono-regulatory disturbance and metabolic costs. Aquatic Toxicol 50: 231243.

MONTEIRO DA, THOMAZ JM, RANTIN FT AND KALININ AL. 2013. Cardiorespiratory responses to graded hypoxia in the neotropical fish matrinxã (Brycon amazonicus) and traíra (Hoplias malabaricus) after waterborne or trophic exposure to inorganic mercury. Aquatic Toxicol 140-141: 346-355. 
NADMitov B, Hong S, IN Kang S, CHU JM, GOMBOEV B, JANCHIVDORJ L, LEE CH AND KHIM JS. 2015. Largescale monitoring and assessment of metal contamination in surface water of the Selenga River Basin (2007-2009). Environ Sci Pollut Res Int 22(4): 2856-2867.

Noureddine D, Miloud S AND ABDElKader A. 2005. Effect of lead exposure on dopaminergic transmission in the rat brain. Toxicology 207(3): 363-368.

PATEl M, Rogers JT, PANe EF AND Wood CM. 2006. Renal responses to acute lead waterborne exposure in the freshwater rainbow trout (Oncorhynchus mykiss). Aquatic Toxicol 80: 362-371.

PETERA JAL AND ViraraghavanB T. 2005. A review of public health and environmental concerns. Environ Int 31: 493-501.

PRotano C, ZinNÀ L, GiAmpaOli S, Romano SPICA V, CHIAVARINI S AND Vitali M. 2014. Heavy metal pollution and potential ecological risks in rivers: a case study from southern Italy. Bull Environ Contam Toxicol. 92(1): 75-80.

PRADO PS, SouzA CC, BAZzoli N AND Rizzo E. 2011. Reproductive disruption in lambari Astyanax fasciatus from a Southeastern Brazilian reservoir. Ecotox Environ Safe 74: 1879-1887.

RabitTo IS, Alves Costa JRM, Silva de Assis HC, Pelletier E, AKAishi FM, ANJOS A, RANDi MAF AND OLIVEIRA RIBEIRO CA. 2005. Effects of dietary $\mathrm{Pb}$ and tributyltin on neotropical fish, Hoplias malabaricus: histopathological and biochemical findings. Ecotoxicol Environ Safe 60: 147-156.

RIBEIRO HJ, PROCÓPIO MS, GOMES JM, VIEIRA FO, RUSSO RC, BALZUWEIT K, CHIARINI-GARCiA H, CASTRO AC, RIZZO E AND CORRÊA JD. 2011. Functional dissimilarity of melanomacrophage centres in the liver and spleen from females of the teleost fish Prochilodus argenteus. Cell Tissue Res 346: 417-425.

RoubaCH R, CORREIA ES, ZAIDEN S, MARTINO RC AND CAVALLI RO. 2003. Aquaculture in Brazil. World Aquacult 34: 28-34.

SAntos HB, Rizzo E, BAzzoli N, SATO Y AND Moro L. 2005. Ovarian regression and apoptosis in the South American teleost Leporinus taeniatus Lutken (Characiformes, Anostomidae) from the São Francisco Basin. J Fish Biol 67: 1446-1459.

SCHMitT CJ, CALDWELl CA, OLSEN B, SERDAR D AND COFFEY M. 2002. Inhibition of erythrocyte deltaaminolevulinic acid dehydratase activity in fish from waters affected by lead smelters. Environ Monit Assess 77: 99-119.

SeIXAs TG, Moreira I, MALM O AND KeHRIG HA. 2012. Mercury and selenium in a toppredator fish, Trichiurus lepturus (Linnaeus, 1758), from the Tropical Brazilian Coast, Rio de Janeiro. Bull Environ Contam Toxicol 89: 434-438.

SEllanes AG, Marsico ET, SANTOS NN, SÃo Clemente SC, OLIVEIRA GA AND MONTEIRO ABS. 2002. Mercúrio em peixes marinhos. Acta Scient Vet 30: 107-112.

SINDAYIGAYA E, VAN CAUWENBERGH R, ROBBERECHT H AND DEELSTRA H. 1994. Copper, zinc, manganese, iron, lead, cadmium, mercury, and arsenic in fish from Lake Tanganyika, Burundi. Sci Total Environ 144: 103-115.

SLOMAN KA. 2007. Effect of trace metals on salmonid fish. The role of social hierarchies. Appl Anim Behav Sci 104: 326-345.

TAWEel A, SHUHAIMI-OTHMAN M AND AHMAD AK. 2013. Assessment of heavy metals in tilapia fish (Oreochromis niloticus) from the Langat river and Engineering lake in Bangi, Malaysia, and evaluation of health risk from tilapia consumption. Ecotoxicol Environ Safe 93: 45-51.

ULUTURHAN E AND KUCUKSEZGIN F. 2007. Heavy metal contaminants in Red Pandora (Pagellus erythrinus) tissues from the Eastern Aegean Sea, Turkey. Water Res 41: 11851192.

U.S EPA 3052 - UNITED STATES ENVIRONMENTAL PROTECTION AGENCY. 1996. Microwave assisted acid digestion of siliceous and organically based matrices.

U.S EPA 7473 - UNITED STATES ENVIRONMENTAL PROTECTION AGENCY. 1998. Mercury in Solids and Solutions by Thermal Decomposition, Amalgamation and Atomic Absorption Spectrophotometry.

VITEK T, SPURNY P, MARES J AND ZIKOVA A. 2007. Heavy metal contamination of the Loucka River water ecosystem. Acta Vet Brno 76: 149-154.

VOGELBEIN WK, FOURNIE JW AND OVERSTREET RM. 1987. Sequential development and morphology of experimentally induced hepatic melanomacrophage centres in Rivulus marmoratus. J Fish Biol 31: 145-153.

XIE Z, SUN Z, ZHANG H AND ZHAI J. 2014. Contamination assessment of arsenic and heavy metals in a typical abandoned estuary wetland-a case study of the Yellow River Delta Natural Reserve. Environ Monit Assess 186(11): 7211-7232.

Xu T, HuAng Y AND CHen J. 2014. Metal Distribution in the Tissues of Two Benthic Fish from Paddy Fields in the Middle Reach of the Yangtze River. Bull Environ Contam Toxicol 92(4): 446-450.

XU YJ, LIU XZ AND MA AJ. 2004. Current Research on Toxicity Effect and Molecular Mechanism of Heavy Metals on Fish. Mar Sci 28: 67-70.

Youn-JOO A. 2003. Total, dissolved, and bioaccumulation in freshwater fish with emphasis on the dietary influence. Water Res 34: 4234-4242. 